A

\title{
Research Article: Impact of cluster front line demonstration on oilseed crop in Barpeta district of Assam
}

\author{
¿hittaranjan Deka, A.K. Deka, P. Barman and M. Mudoi
}

Article Chronicle:

Received :

20.04.2020;

Revised:

03.06.2020;

Accepted :

04.07.2020

KeY Words :

Impact, CFLD, Adoption, Yield, Economic, Horizontal

Author for correspondence :

Chittaranjan Deka

Krishi Vigyan Kendra

(A.A.U.), Barpeta (Assam) India

Email: chittasarthebari@ gmail.com

See end of the article for authors' affiliations
SUMMARY : The main objective of cluster front line demonstrations (CFLDs) is to demonstrate newly released crop production and protection technologies and its management practices at the farmer's field in cluster approach under different agro-climatic regions and farming situations. Pointing the importance of cluster frontline demonstrations in transfer of oilseed production technologies, Krishi Vigyan Kendra, Barpeta conducted CFLDs at farmers' field and accordingly study was conducted in Barpeta district of Assam. The study revealed that important package of practices where more increase in adoption was found were use of high yielding variety of rapeseed Var-TS-38 (72.5\%), seed treatment $(67.5 \%)$, use of proper seed rate $(65.0 \%)$, recommended fertilizer dose $(57.5 \%)$, line sowing on furrows $(40.0 \%)$, weed management $(27.5 \%)$ and sowing time (30.0\%). There was noteworthy difference observed in yield of oilseed before conductance of CFLD and after CFLD programme. B:C ratio of oilseed crop after CFLD was higher than before CFLD. It showed impact of CFLD on adoption of oilseed production technologies. The factors responsible for low B:C ratio before CFLD was less adoption of all the recommended package of practices for oilseed crop in the region.

How to cite this article : Deka, Chittaranjan, Deka, A.K., Barman, P. and Mudoi, M. (2020). Impact of cluster front line demonstration on oilseed crop in Barpeta district of Assam. Agric. Update, 15(3): 157-161; DOI : 10.15740/HAS/AU/15.3/157-161. Copyright@2020: Hind Agri-Horticultural Society. 